\title{
Optimasi Pengujian Daya Berkecambah dan Faktor yang Mempengaruhi Viabilitas dan Vigor Benih Kelor (Moringa oleifera Lam.) dalam Penyimpanan
}

\author{
Optimization of Germination Test and Factors Influencing Seed Viability and Vigor of Moringa \\ (Moringa oleifera Lam.) in the Storage
}

\section{Kurniati Endah Paramita, Tatiek Kartika Suharsi* dan Memen Surahman}

\author{
Departemen Agronomi dan Hortikultura, Fakultas Pertanian, Institut Pertanian Bogor (Bogor Agriculture \\ University), Jl. Meranti, Kampus IPB Dramaga, Bogor 16680, Indonesia \\ Telp. \& Faks, 0251-8629353 e-mail: agronipb@indo.net.id \\ *Penulis untuk korespondensi : tsuharsi@yahoo.co.id
}

Disetujui 14 Mei 2018 / Published online 21 Mei 2018

\begin{abstract}
Moringa (Moringa oleifera Lam.) is a commodity that has high economic value. The increasing demand for moringa needs to be supported by the availability of high quality seeds. Quality seeds were affected by germination and seed storage technology. This experiment aimed to study the optimization germination test of moringa seed and to determine the effect of packaging and different room storage condition on seed viability and vigor during storage period. This research was conducted at the Laboratory of Seed Science and Technology, Bogor Agricultural University and greenhouse, experimental field at Leuwikopo, Bogor Agricultural University Dramaga, from April-October 2016. Optimization germination test consisted of observations for first count and final count and the effect of wing treatment and fruit maturity seed on viability. First count observations was done on 10th day and the final count on 15th day after the germination. This research used in sand method for germination test. During the 6 months storage period, moringa seed stored in aluminum foil and plastic package on the air conditioner (AC) temperature (17-19 $\left.{ }^{\circ} \mathrm{C}\right)$ and room temperature $\left(27-29{ }^{\circ} \mathrm{C}\right)$ has better water content, viability and vigor than the seed stored in paper package. The seed stored in aluminum foil package has the best average of water content $(7,75 \%)$, viability (growth potency of 86,22\%) and vigor (growth speed of 9,58\% KN /etmal), while the use of plastic package has the best average of viability (germination capacity of $82,11 \%$ ) and vigor (vigor index of $66,83 \%)$. The storage at AC temperature mantained water contain, viability and vigor better than room temperature storage.
\end{abstract}

Keywords: final count, first count, seed maturity, seed storage, wing treatment

ABSTRAK

Kelor (Moringa oleifera Lam.) merupakan komoditas yang memiliki nilai ekonomi tinggi. Adanya permintaan kelor yang semakin meningkat perlu didukung ketersedian benih bermutu. Benih bermutu dipengaruhi oleh daya berkecambah dan teknologi penyimpanan benih yang tepat. Penelitian ini bertujuan mempelajari optimasi pengujian daya berkecambah benih kelor dan untuk mengetahui pengaruh faktor kemasan dan kondisi ruang simpan terhadap viabilitas dan vigor benih selama penyimpanan. Penelitian dilakukan di Laboratorium Ilmu dan Teknologi Benih IPB dan rumah kaca kebun percobaan Leuwikopo, IPB Dramaga, pada bulan April-Oktober 2016. Optimasi pengujian daya berkecambah meliputi pengamatan first count dan final count serta pengaruh perlakuan pemotongan sayap benih dan kemasakan buah terhadap viabilitas. Hasil pengamatan first count jatuh pada hari ke-10 dan final count pada hari ke-15 setelah benih ditanam. Selama periode simpan 6 bulan, penyimpanan benih kelor dalam kemasan aluminium foil dan plastik pada suhu AC $\left(17-19^{\circ} \mathrm{C}\right)$ dan suhu kamar $\left(27-29{ }^{\circ} \mathrm{C}\right)$ memberikan hasil $\mathrm{KA}$, viabilitas dan vigor lebih baik dibandingkan kemasan kertas. Penyimpanan dalam kemasan aluminium foil memberikan hasil rata-rata KA $(7,75 \%)$, viabilitas (PTM 86,22\%), dan vigor $\left(\mathrm{K}_{\mathrm{CT}} 9,58 \% \mathrm{KN} /\right.$ etmal $)$ terbaik, sedangkan penyimpanan menggunakan plastik memberikan hasil rata-rata viabilitas (DB 82,11\%), dan vigor (IV 66,83\%) terbaik. Penyimpanan menggunakan suhu AC lebih baik dalam mempertahankan KA, viabilitas, dan vigor dibandingkan suhu kamar.

Kata kunci: final count, first count, kemasakan buah, penyimpanan benih, perlakuan pemotongan sayap benih 


\section{PENDAHULUAN}

Kelor (Moringa oleifera Lam.) merupakan tanaman perdu yang berasal dari kaki gunung Himalaya, Asia Selatan dan timur laut Pakistan (Kasolo et al., 2010). Seiring dengan berkembangnya informasi mengenai manfaatnya, kelor mulai diperkenalkan dan dibudidayakan hampir di seluruh belahan dunia, antara lain, Asia Tenggara, Afrika, Amerika Tengah, Amerika Selatan, dan Semenanjung Arab (Desiawati, 2013). Kelor dijuluki "Mother's Best Friend" dan "Miracle Tree" atau pohon ajaib karena mengandung zat gizi dan manfaat yang banyak (Mardiana, 2013; Kustiani, 2013). Kelor juga dikembangkan di Indonesia, yang tersebar di seluruh daerah mulai dari Aceh hingga Merauke. Mulai tahun 2014 kelor menjadi komoditas yang sangat dicari dan mulai banyak dibudidayakan untuk tujuan ekonomi, terutama untuk dijual daunnya. Sentra produksi kelor terbesar di Indonesia terletak di Kupang, Nusa Tenggara Timur yang memiliki kelor kualitas terbaik nomor dua di dunia setelah Spanyol (Kompas, 2015).

Tanaman kelor menjadi komoditas yang memiliki nilai ekonomi tinggi, hal ini terbukti dengan adanya permintaan ekspor daun kelor Provinsi Nusa Tenggara Timur (NTT) ke Spanyol dan permintaan sepuluh ribu ton bibit kelor ke Cina (Winarno, 2014). Permintaan ini belum dapat dipenuhi karena produksi yang masih terbatas. Diperlukan cara perbanyakan yang tepat untuk memenuhi permintaan ekspor kelor yang semakin meningkat. Perbanyakan kelor dapat dilakukan dengan benih dan stek. Perbanyakan tanaman dengan benih perlu didukung ketersediaan benih bermutu. Benih bermutu di antaranya dapat dilihat dari daya berkecambah. Daya berkecambah (DB) adalah tolok ukur bagi kemampuan benih untuk tumbuh normal dan berproduksi normal pada kondisi lingkungan yang optimum (Widajati et al., 2013). Hingga kini periode pengamatan pertama (first count) dan kedua (final count) dalam pengujian DB untuk komoditas kelor belum diketahui, oleh karena itu perlu dilakukan penelitian untuk menentukan periode pengamatannya.

Tingkat kemasakan buah dan perlakuan benih merupakan faktor yang mempengaruhi perkecambahan benih. Tingkat kemasakan buah berhubungan dengan momen masak fisiologis benih. Benih yang dipanen saat masak fisiologis memiliki vigor dan DB maksimum. Penentuan masak fisiologis benih dapat berdasarkan deskripsi tanaman atau karakter morfologis yang praktis di lapangan. Kemasakan buah kelor lebih mudah dikenali dari warna kulit luar buah, yaitu saat muda berwarna hijau dan akan menjadi coklat saat sudah tua. Pengetahuan tentang karakteristik buah saat masak fisiologi benih kelor digunakan untuk menentukan waktu panen yang tepat sehingga didapatkan benih bermutu. Benih kelor memiliki struktur seperti sayap berwarna putih yang mengelilingi embrio. Struktur sayap ini belum diketahui pengaruhnya terhadap perkecambahan benih. Optimasi daya berkecambah dapat dilakukan dengan menggunakan tingkat kemasakan buah dan perlakuan benih yang tepat.

Benih yang telah dipanen biasanya tidak langsung ditanam, seringkali benih harus disimpan selama beberapa hari, minggu, bulan, bahkan bertahuntahun. Teknologi penyimpanan benih yang baik mampu memperlambat kemunduran benih (Widajati et al., 2013). Faktor-faktor yang mempengaruhi viabilitas benih selama penyimpanan meliputi, faktor internal yaitu kadar air, sifat genetik, viabilitas awal dan faktor eksternal yaitu suhu dan kelembaban ruang simpan, kemasan, mikroorganisme, dan manusia. Penelitian ini dilakukan untuk mengetahui pengaruh faktor kemasan dan kondisi ruang simpan terhadap viabilitas dan vigor benih kelor selama penyimpanan.

\section{BAHAN DAN METODE}

Penelitian berlangsung dari bulan April sampai Oktober 2016. Penelitian dilaksanakan di Laboratorium Ilmu dan Teknologi Benih dan rumah kaca Kebun Percobaan Leuwikopo, Departemen Agronomi dan Hortikultura, IPB Dramaga. Benih kelor yang digunakan diperoleh dari petani produsen di Provinsi Sulawesi Selatan. Benih diekstraksi dari dua tingkat kemasakan yang berbeda yaitu kulit buah berwana hijau kecoklatan dan kulit buah berwarna coklat tua. Bahan lain yang digunakan adalah pasir, kantong plastik, kantong aluminium foil, kantong kertas, akuades, air bersuhu $60{ }^{\circ} \mathrm{C}$, dan larutan natrium hipoklorit $(\mathrm{NaClO}) 1 \%$. Peralatan yang digunakan adalah seperangkat alat tulis, kamera, gelas ukur, hygrometer, termometer, mika plastik untuk perkecambahan, amplop, label, selotip, sealer, timbangan digital, drying container (wadah untuk kadar air), desikator, dan oven.

Penelitian ini terdiri atas dua percobaan, yaitu :

1) optimasi pengujian daya berkecambah benih kelor,

2) pengaruh kemasan dan kondisi ruang simpan terhadap viabilitas dan vigor benih kelor selama penyimpanan. 
Percobaan 1 menggunakan Rancangan Acak Lengkap dengan 2 faktor. Faktor pertama adalah perlakuan pemotongan sayap benih (benih dengan sayap dan benih tanpa sayap), sedangkan faktor kedua adalah tingkat kemasakan buah (buah berwarna hijau kecoklatan dan buah berwarna coklat tua). Terdapat empat kombinasi perlakuan yang diulang sebanyak empat kali sehingga diperoleh 16 satuan percobaan. Pelaksanaan percobaan 1 diawali dengan ekstraksi benih dari buah berwarna hijau kecoklatan dan coklat tua, kemudian dilakukan sortasi benih secara manual dengan parameter benih memiliki ukuran dan warna seragam, tidak cacat, dan bebas dari hama dan penyakit. Pengujian kadar air dilakukan setelah sortasi benih. Perlakuan tanpa sayap benih dengan membuang sayap disekeliling benih, sedangkan perlakuan benih dengan sayap tidak dilakukan pemotongan. Sebelum benih ditanam, benih direndam air dengan suhu awal 60 ${ }^{0} \mathrm{C}$ selama 24 jam. Benih ditanam dalam bak dengan media pasir yang telah disterilkan, dimana satu bak ditanam 25 benih kelor. Bak diletakkan di dalam rumah kaca. Pemeliharaan perkecambahan dilakukan dengan penyiraman dan penyiangan. Percobaan 1 terdiri dari dua pengamatan, yaitu pengamatan first count dan final count serta pengaruh perlakuan pemotongan sayap dan kemasakan buah (parameter daya berkecambah dan indeks vigor). Pengamatan dilakukan setiap hari dengan perhitungan terhadap kecambah normal (KN) selama 22 hari. Penentuan first count dilakukan dengan menentukan jumlah persentase kecambah normal harian tertinggi secara visual, sedangkan penentuan final count dilakukan dengan menentukan jumlah persentase kecambah normal kumulatif tertinggi. Data hasil pengamatan dianalisis menggunakan uji $\mathrm{F}$, jika terdapat hasil yang berbeda nyata maka analisis dilanjutkan dengan uji lanjut Duncan Multiple Range Test (DMRT) dengan taraf 5\%.

Percobaan 2 menggunakan rancangan petak tersarang (nested design) dengan dua faktor. Faktor pertama adalah jenis kemasan (plastik, kertas, dan aluminium foil). Faktor kedua adalah suhu ruang simpan (suhu AC dan suhu kamar). Masing-masing perlakuan diulang 3 kali dan ulangan tersarang dalam suhu ruang simpan, sehingga terdapat 18 satuan percobaan. Sebelum benih disimpan dilakukan pengujian kadar air. Benih yang dikemas hanya yang berasal dari buah berwarna coklat tua tanpa menghilangkan sayap benih. Benih dimasukkan ke dalam kemasan plastik, kertas, dan aluminium foil sebanyak 30 benih setiap kemasan. Benih yang sudah dikemas disimpan pada dua kondisi ruang simpan, yaitu ruang simpan suhu $\mathrm{AC}$ (suhu $=17-19^{\circ} \mathrm{C}, \mathrm{RH}=$ 49-55\%) dan ruang simpan suhu kamar (suhu = $27-29{ }^{\circ} \mathrm{C}, \mathrm{RH}=68-80 \%$ ). Benih disimpan selama 6 bulan dan pengujian kadar air, viabilitas, dan vigor benih dilakukan setiap satu bulan sekali. Sebelum benih dikecambahkan, benih direndam larutan natrium hipoklorit $1 \%$ selama 5 menit, kemudian direndam air dengan suhu awal $60{ }^{\circ} \mathrm{C}$ selama 24 jam. Perkecambahan benih sama seperti percobaan 1. Pengamatan viabilitas dilakukan pada tolok ukur potensi tumbuh maksimum (PTM), daya berkecambah (DB), dan berat kering kecambah normal (BKKN), sedangkan vigor benih dilakukan pada tolok ukur indeks vigor (IV) dan kecepatan tumbuh benih $\left(\mathrm{K}_{\mathrm{CT}}\right)$. Data hasil pengamatan dianalisis menggunakan uji $\mathrm{F}$, jika terdapat hasil yang berbeda nyata maka analisis dilanjutkan dengan uji lanjut Duncan Multiple Range Test (DMRT) dengan taraf 5\%. Pengukuran suhu dan RH ruang simpan juga dilakukan sebagai data pendukung.

\section{HASIL DAN PEMBAHASAN}

\section{Kondisi Umum}

Benih kelor berbentuk segitiga bulat, memiliki struktur sayap berwarna putih di sekeliling benihnya yang berwarna hitam. Berdasarkan posisi embrio, benih kelor merupakan benih basal. Bagian basal adalah bagian yang lebih tumpul, ini adalah tempat munculnya akar dan plumula. Rumah kaca kebun percobaan Leuwikopo, IPB, Dramaga memiliki suhu antara $28-34{ }^{0} \mathrm{C}$ dan kelembaban relatif (RH) berkisar $64-90 \%$. Kondisi ini merupakan kondisi ideal untuk pertumbuhan kelor, karena menurut Radovich (2009) suhu rata-rata harian untuk pertumbuhan kelor adalah $15-30{ }^{\circ} \mathrm{C}$ dan jika dibawah $20{ }^{\circ} \mathrm{C}$ pertumbuhan akan lambat.

\section{Percobaan 1}

Optimasi Daya Berkecambah Benih Kelor. Penentuan First Count dan Final Count berdasarkan nilai jumlah kecambah normal harian dan nilai jumlah kecambah normal kumulatif tertinggi dari setiap kombinasi perlakuan benih dan tingkat kemasakan buah yang ditunjukkan pada scatter plot, maka didapatkan data first count dan final count dari keempat populasi (Tabel 1). 
Tabel 1. First count dan final count dari setiap kombinasi perlakuan

\begin{tabular}{lcccr}
\hline \multirow{2}{*}{ Perlakuan } & \multicolumn{2}{c}{ First Count (hari ke-) } & \multicolumn{2}{c}{ Final Count (hari ke-) } \\
\cline { 2 - 5 } & buah hijau kecoklatan & buah coklat tua & buah hijau kecoklatan & buah coklat tua \\
\hline Benih dengan sayap & 10 & 10 & 15 & 15 \\
Benih tanpa sayap & 10 & 9 & 15 & 15 \\
\hline
\end{tabular}

First count dan final count ditentukan dengan melihat data first count dan final count yang paling sering muncul pada kedua populasi. First count yang paling sering muncul pada kedua populasi yaitu hari ke-10 setelah pengecambahan, yaitu 3 kali muncul. Data final count menunjukkan hasil yang sama, yaitu pada hari ke15. Hasil dari percobaan pertama, digunakan untuk menghitung peubah pada percobaan kedua.

\section{Pengaruh Perlakuan Pemotongan Sayap Benih dan}

Kemasakan Buah terhadap Perkecambahan Benih

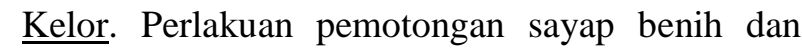
kemasakan buah maupun interaksinya tidak berpengaruh nyata pada semua tolok ukur yang diamati (kadar air, daya berkecambah, dan indeks vigor). Tabel 2 menunjukkan bahwa benih tanpa sayap memiliki tingkat serangan cendawan yang lebih rendah, yaitu 0,86 namun menyebabkan kematian benih lebih besar $(3,38)$ daripada benih utuh $(0,86)$. Dilihat dari segi efisiensi, perkecambahan benih dengan sayap lebih praktis dilakukan karena saat ini belum ada alat untuk menghilangkan struktur sayap benih kelor secara otomatis, sehingga apabila perkecambahan dilakukan dalam skala besar membutuhkan waktu lebih lama. Serangan cendawan pada benih dengan sayap dapat diatasi dengan sterilisasi benih menggunakan natrium hipoklorit $(\mathrm{NaClO})$ sebelum dikecambahkan. Menurut Widajati et al. (2013), benih bersayap merupakan adaptasi untuk anemochory, sayap terbentuk karena perkembangan testa yang berfungsi sebagai sarana untuk terbang (seed flyer).

Tabel 2. Pengaruh perlakuan pemotongan sayap benih dan kemasakan buah terhadap jumlah benih mati dan bercendawan

\begin{tabular}{lcc}
\hline \multicolumn{1}{c}{ Faktor perlakuan } & Jumlah benih mati & Jumlah benih bercendawan \\
\hline Perlakuan pemotongan sayap benih & & \\
Benih dengan sayap & $0,86^{\mathrm{a}}$ & $3,25^{\mathrm{a}}$ \\
Benih tanpa sayap & $3,38^{\mathrm{b}}$ & $0,86^{\mathrm{b}}$ \\
\hline Tingkat kemasakan buah & & \\
Buah hijau kecoklatan & 2,38 & 1,86 \\
Buah coklat tua & 1,88 & 2,25 \\
\hline
\end{tabular}

Keterangan : angka yang diikuti huruf yang sama pada kolom yang sama menunjukkan tidak berbeda nyata dengan uji DMRT taraf $\alpha$ $=5 \%$

Dua tingkat kemasakan buah yang digunakan pada penelitian ini juga tidak berpengaruh nyata pada tolok ukur yang diamati. Tingkat kematian benih dan serangan cendawan juga tidak berpengaruh nyata (Tabel 2). Hal ini mengindikasikan bahwa kelor dengan kulit buah berwana hijau kecoklatan telah mencapai masak fisiologi, tanpa harus menunggu menjadi coklat tua. Masak fisiologi merupakan stadia pertumbuhan yang penting bagi tanaman karena berhubungan dengan akumulasi maksimum berat kering benih, vigor benih, serta hasil yang maksimum (Ilyas, 2012).

\section{Percobaan II}

Pengaruh Kemasan dan Ruang Simpan terhadap Viabilitas dan Vigor Benih Kelor selama Penyimpanan. Kondisi awal benih sebelum simpan berdasarkan hasil dari percobaan I, penyimpanan benih hanya dilakukan pada benih bersayap dan berasal dari buah berwana coklat tua, hal ini dikarenakan adanya keterbatasan jumlah benih dari buah berwana hijau kecoklatan. Viabilitas awal dan kadar air benih awal sangat menentukan umur simpan benih, dimana selama masa penyimpanan yang terjadi adalah penurunan viabilitas awal tersebut (Sutopo, 2010). Kondisi awal benih kelor sebelum disimpan yaitu memiliki kadar air 7,62\% dan daya berkecambah 78,67\% (Tabel 3). 
Tabel 3. Viabilitas dan vigor awal benih kelor sebelum perlakuan penyimpanan

\begin{tabular}{lc}
\hline Peubah & Nilai \\
\hline Kadar air (\%) & 7,62 \\
Potensi tumbuh maksimum (\%) & 82,67 \\
Daya berkecambah (\%) & 78,67 \\
Berat kering kecambah normal $(\mathrm{g})$ & 0,50 \\
Indeks vigor (\%) & 40,67 \\
Kecepatan tumbuh (\%KN/etmal) & 7,60 \\
\hline
\end{tabular}

Penyimpanan Benih Kelor. Rekapitulasi sidik ragam menunjukkan bahwa faktor jenis kemasan berpengaruh nyata pada peubah kadar air (2 BSS), daya berkecambah (5 BSS), indeks vigor (3 dan 5 BSS), dan kecepatan tumbuh (4-5 BSS), sedangkan faktor ruang simpan berpengaruh nyata pada peubah kadar air (3 dan 5 BSS) dan potensi tumbuh maksimum (5 BSS). Interaksi antara kedua faktor berpengaruh nyata pada peubah kadar air (2 dan 4 BSS), potensi tumbuh maksimum (4 BSS), daya berkecambah (5 BSS), dan kecepatan tumbuh (5 BSS).
Pengaruh Kemasan dan Ruang Simpan terhadap Kadar Air. Kadar air (KA) benih awal sebelum disimpan (0 BSS) adalah 7,62\%, setelah mengalami perlakuan kemasan dan kondisi ruang simpan KA benih mengalami fluktuasi. Benih yang disimpan dalam plastik memiliki KA terendah $(7,46 \%)$ dibandingkan benih dalam kemasan kertas dan aluminium foil $(8,76 \%$ dan $8,21 \%$ ) pada 2 BSS (Tabel 4). Hal ini sesuai dengan pernyataan Justice dan Bass (2002), bahwa kemasan kertas dapat melindungi mutu fisik benih, tetapi tidak dapat melindungi benih dari pengaruh suhu dan kelembaban nisbi di sekelilingnya sehingga memiliki KA tertinggi.

Tabel 4. Kadar air (\%) benih kelor yang disimpan pada berbagai jenis kemasan dan ruang simpan selama 6 bulan

\begin{tabular}{|c|c|c|c|c|c|c|c|}
\hline & \multirow{2}{*}{ Perlakuan } & \multicolumn{6}{|c|}{ Periode simpan (BSS) } \\
\hline & & 1 & 2 & 3 & 4 & 5 & 6 \\
\hline \multirow[t]{4}{*}{1} & Jenis kemasan & & & & & & \\
\hline & Plastik & 8,02 & $7,46^{\mathrm{b}}$ & 7,52 & 8,05 & 7,95 & 8,93 \\
\hline & Kertas & 7,49 & $8,76^{\mathrm{a}}$ & 8,35 & 7,87 & 8,69 & 8,22 \\
\hline & Aluminium foil & 7,14 & $8,21^{\mathrm{a}}$ & 7,61 & 7,17 & 8,52 & 8,31 \\
\hline \multirow[t]{3}{*}{2} & Ruang simpan & & & & & & \\
\hline & Suhu AC $\left(17-19^{\circ} \mathrm{C}\right)$ & 7,16 & 7,56 & $7,28^{\mathrm{b}}$ & 7,17 & $7,89^{\mathrm{b}}$ & 8,41 \\
\hline & Suhu kamar $\left(27-29^{\circ} \mathrm{C}\right)$ & 7,95 & 8,73 & $8,37^{\mathrm{a}}$ & 8,21 & $8,89^{\mathrm{a}}$ & 8,56 \\
\hline
\end{tabular}

Keterangan : angka yang diikuti huruf yang sama pada kolom yang sama menunjukkan tidak berbeda nyata dengan uji DMRT taraf $\alpha$ $=5 \%, \mathrm{BSS}=$ bulan setelah simpan

Berdasarkan hasil dari percobaan I, penyimpanan benih hanya dilakukan pada benih bersayap dan berasal dari buah berwana coklat tua, hal ini dikarenakan adanya keterbatasan jumlah benih dari buah berwana hijau kecoklatan. Viabilitas awal dan kadar air benih awal sangat menentukan umur simpan benih, dimana selama masa penyimpanan yang terjadi adalah penurunan viabilitas awal tersebut (Sutopo, 2010). Kondisi awal benih kelor sebelum disimpan yaitu memiliki kadar air 7,62\% dan daya berkecambah 78,67\% (Tabel 3).

Penyimpanan Benih Kelor. Rekapitulasi sidik ragam menunjukkan bahwa faktor jenis kemasan berpengaruh nyata pada peubah kadar air (2 BSS), daya berkecambah (5 BSS), indeks vigor (3 dan 5 BSS), dan kecepatan tumbuh (4-5 BSS), sedangkan faktor ruang simpan berpengaruh nyata pada peubah kadar air (3 dan 5 BSS) dan potensi tumbuh maksimum (5 BSS). Interaksi antara kedua faktor berpengaruh nyata pada peubah kadar air (2 dan 4 BSS), potensi tumbuh maksimum (4 BSS), daya berkecambah (5 BSS), dan kecepatan tumbuh (5 BSS).

Pengaruh Kemasan dan Ruang Simpan terhadap Kadar Air. Kadar air (KA) benih awal sebelum disimpan (0 BSS) adalah 7,62\%, setelah mengalami perlakuan kemasan dan kondisi ruang simpan KA benih mengalami fluktuasi. Benih yang disimpan dalam plastik memiliki KA terendah $(7,46 \%)$ dibandingkan benih dalam kemasan kertas dan aluminium foil $(8,76 \%$ dan $8,21 \%$ ) pada 2 BSS (Tabel 4). Hal ini sesuai dengan pernyataan Justice dan Bass (2002), 
bahwa kemasan kertas dapat melindungi mutu fisik benih, tetapi tidak dapat melindungi benih dari pengaruh suhu dan kelembaban nisbi di sekelilingnya sehingga memiliki KA tertinggi.

Tabel 5. Potensi tumbuh maksimum benih kelor yang disimpan pada berbagai jenis kemasan dan ruang simpan selama 6 bulan

\begin{tabular}{lcccccc}
\hline \multirow{2}{*}{ Perlakuan } & \multicolumn{7}{c}{ Periode simpan (BSS) } \\
\cline { 2 - 7 } & 1 & 2 & 3 & 4 & 5 & 6 \\
\hline $1 \quad$ Jenis kemasan & 82,00 & 88,67 & 86,55 & 89,33 & 84,00 & 80,67 \\
$\quad$ Plastik & 84,67 & 88,00 & 82,67 & 88,33 & 84,00 & 83,33 \\
$\quad$ Kertas & 80,00 & 86,67 & 91,33 & 84,00 & 90,00 & 85,33 \\
$\quad$ Aluminium foil & & & & & & \\
$\quad$ Ruang simpan & 82,67 & 88,44 & 85,70 & 89,11 & $88,44^{\mathrm{a}}$ & 86,67 \\
$\quad$ Suhu AC $\left(17-19^{0} \mathrm{C}\right)$ & 81,78 & 87,11 & 88,00 & 85,33 & $83,56^{\mathrm{b}}$ & 79,56 \\
\hline
\end{tabular}

Penyimpanan pada ruang simpan suhu AC memiliki PTM nyata lebih tinggi $(88,44 \%)$ dibandingkan ruang simpan suhu kamar $(83,56 \%)$ pada 5 BSS (Tabel 5). PTM benih awal sebelum simpan adalah $82,67 \%$, pada akhir pengujian (6 BSS) penyimpanan pada suhu AC mampu mempertahankan PTM lebih baik dibandingkan suhu kamar, dimana suhu AC memiliki PTM $86,67 \%$ dan suhu kamar memiliki PTM 79,56\% (Tabel 5). Hal ini karena penyimpanan suhu AC memiliki suhu dan $\mathrm{RH}$ yang lebih rendah sehingga kemunduran viabilitas benih dapat dikurangi (Justice dan Bass, 2002).

Viabilitas Potensial Benih (Tolok ukur Daya Berkecambah dan Berat Kering Kecambah Normal) Benih yang disimpan pada kemasan aluminium foil periode simpan 5 bulan, memiliki DB yang tidak berbeda nyata dengan kemasan plastik, dan kemasan kertas memiliki DB terendah $(80,00 \%)$ (Tabel 6). Hal ini sesuai dengan penelitian Nazimah (2010) yang menunjukkan bahwa benih purwoceng (Pimpinella pruatjan) yang disimpan pada kemasan plastik dan aluminium foil memiliki DB lebih tinggi dibandingkan kemasan kertas. Daya berkecambah benih sebelum disimpan adalah 78,67\% (Tabel 3). Terjadi fluktuasi DB selama periode simpan benih, pada 6 BSS kemasan aluminium foil paling baik dalam mempertahankan viabilitas karena memiliki nilai DB tertinggi yaitu $80,00 \%$ (Tabel $6)$.

Tabel 6. Daya Berkecambah (\%) benih kelor yang disimpan pada berbagai jenis kemasan dan ruang simpan selama 6 bulan penyimpanan

\begin{tabular}{llcccccc}
\hline \multirow{2}{*}{ Perlakuan } & \multicolumn{7}{c}{ Periode simpan (BSS) } \\
\cline { 2 - 7 } & 1 & 2 & 3 & 4 & 5 & 6 \\
\hline 1 Jenis kemasan & 80,67 & 84,67 & 84,53 & 85,33 & $84,00^{\mathrm{ab}}$ & 75,33 \\
& Plastik & 75,33 & 86,67 & 82,00 & 71,67 & $80,00^{\mathrm{b}}$ & 76,67 \\
& Kertas & 72,67 & 86,00 & 91,33 & 69,33 & $86,67^{\mathrm{a}}$ & 80,00 \\
& Aluminium foil & & & & & & \\
2 & Ruang simpan & 76,00 & 86,22 & 84,80 & 79,33 & 85,78 & 83,56 \\
& Suhu AC $\left(17-19{ }^{0} \mathrm{C}\right)$ & 76,44 & 85,33 & 87,11 & 71,56 & 81,33 & 71,11 \\
& Suhu kamar $\left(27-29{ }^{0} \mathrm{C}\right)$ & &
\end{tabular}

Keterangan : angka yang diikuti huruf yang sama pada kolom yang sama menunjukkan tidak berbeda nyata dengan uji DMRT taraf $\alpha$ $=5 \%, \mathrm{BSS}=$ bulan setelah simpan

Tabel 6 menunjukkan ruang simpan tidak berpengaruh terhadap DB benih kelor. Secara umum penyimpanan pada suhu AC memiliki DB lebih tinggi dibandingkan pada suhu kamar (2, 4,
5, 6 BSS) (Tabel 6). Hal ini karena KA pada suhu kamar lebih tinggi dibandingkan suhu AC, dimana laju kemunduran benih lebih cepat terjadi pada benih dengan KA tinggi (Indartono, 2011). 


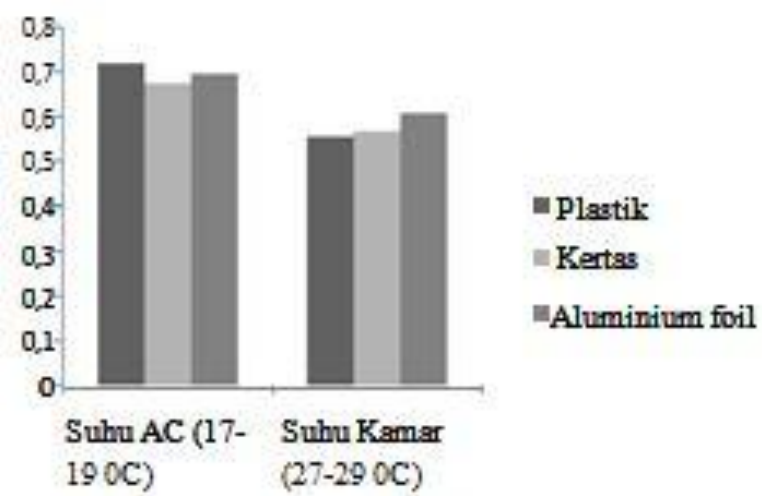

Gambar 1. Interaksi jenis kemasan dan suhu ruang simpan terhadap BKKN benih pada 6 BSS

Perlakuan kemasan, ruang simpan, dan interaksinya tidak berpengaruh nyata pada tolok ukur berat kering kecambah normal (BKKN). Berdasarkan Gambar 1, penyimpanan menggunakan kemasan plastik dan aluminium foil pada suhu AC memiliki BKKN lebih tinggi dibandingkan kemasan kertas. Penyimpanan pada suhu kamar lebih baik menggunakan aluminium foil karena memiliki BKKN tertinggi, adanya suhu yang lebih tinggi tidak begitu mempengaruhi BKKN karena kemasan kedap udara. Secara umum, penyimpanan pada ruang suhu AC memiliki BKKN lebih tinggi dibandingkan suhu kamar pada semua jenis kemasan (Gambar 1).

Pengaruh Jenis Kemasan, Ruang Simpan, dan Interaksinya terhadap Vigor Benih Indeks Vigor. Penyimpanan menggunakan aluminium foil memberikan Indeks Vigor (IV) nyata lebih tinggi dibandingkan penyimpanan dengan kemasan lain pada 3 dan 5 BSS (Tabel 7). Kemasan kertas meiliki IV paling rendah karena terbuat dari bahan porous, sehingga permeabilitas terhadap gas oksigen tinggi (Justice dan Bass, 2002). Hal ini menyebabkan respirasi benih lebih aktif karena oksigen dalam kemasan berada dalam jumlah yang tersedia. Berbeda dengan kemasan aluminium foil dan plastik yang lebih kedap udara, respirasi cenderung lebih lambat sehingga cadangan makanan benih dalam kemasan plastik dan aluminium foil lebih tinggi dibandingkan yang disimpan dalam kemasan kertas. Hal ini menyebabkan pada saat dikecambahkan benih yang disimpan pada kemasan aluminium foil dan plastik memiliki IV lebih tinggi dibanding dari kemasan kertas.

Tabel 7. Indeks vigor (\%) benih kelor yang disimpan pada berbagai jenis kemasan dan ruang simpan selama 6 bulan

\begin{tabular}{|c|c|c|c|c|c|c|c|}
\hline \multirow{2}{*}{\multicolumn{2}{|c|}{ Perlakuan }} & \multicolumn{6}{|c|}{ Periode simpan (BSS) } \\
\hline & & 1 & 2 & 3 & 4 & 5 & 6 \\
\hline \multirow[t]{4}{*}{1} & Jenis kemasan & & & & & & \\
\hline & Plastik & 48,67 & 82,00 & $77,83^{\mathrm{b}}$ & 65,33 & $81,33^{\mathrm{b}}$ & 71,33 \\
\hline & Kertas & 29,33 & 83,33 & $76,67^{\mathrm{b}}$ & 46,67 & $76,00^{\mathrm{c}}$ & 58,00 \\
\hline & Aluminium foil & 44,00 & 83,20 & $87,00^{\mathrm{a}}$ & 49,60 & $87,20^{\mathrm{a}}$ & 68,67 \\
\hline \multirow[t]{3}{*}{2} & Ruang simpan & & & & & & \\
\hline & Suhu AC $\left(17-19{ }^{0} \mathrm{C}\right)$ & 36,44 & 83,11 & 79,67 & 56,00 & 83,56 & 71,56 \\
\hline & Suhu kamar $\left(27-29{ }^{0} \mathrm{C}\right)$ & 44,89 & 81,78 & 81,33 & 51,11 & 79,11 & 60,44 \\
\hline
\end{tabular}

Keterangan : angka yang diikuti huruf yang sama pada kolom yang sama menunjukkan tidak berbeda nyata dengan uji DMRT taraf $\alpha$ $=5 \%, \mathrm{BSS}=$ bulan setelah simpan

Penyimpanan mengunakan plastik dan aluminium foil pada 6 BSS memiliki IV lebih tinggi dibandingkan kemasan kertas pada masingmasing ruang simpan. Penyimpanan pada suhu
AC menunjukkan hasil IV lebih baik dibandingkan suhu kamar untuk semua jenis kemasan yang digunakan (Gambar 2). 


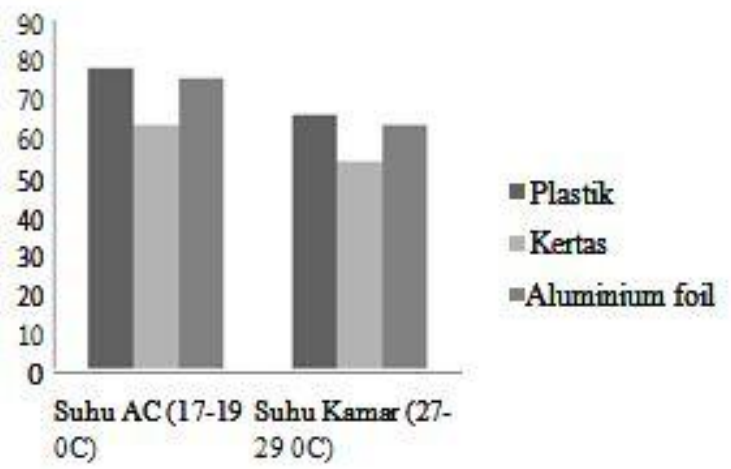

Gambar 2. Interaksi jenis kemasan dan suhu ruang simpan terhadap indeks vigor benih pada 6 BSS

Kecepatan Tumbuh Benih. Kecepatan tumbuh $\left(\mathrm{K}_{\mathrm{CT}}\right)$ benih merupakan tolok ukur yang mengindikasikan vigor kekuatan tumbuh $\left(\mathrm{V}_{\mathrm{KT}}\right)$ dan merupakan tolok ukur yang lebih peka dibandingkan DB. Kemasan plastik memiliki $\mathrm{K}_{\mathrm{CT}}$ tertinggi pada 4 BSS dengan nilai 9,40 $\% \mathrm{KN} /$ etmal, sedangkan pada 5 BSS kemasan aluminium foil memiliki nilai $\mathrm{K}_{\mathrm{CT}}$ tertinggi, yaitu $11,08 \% \mathrm{KN} /$ etmal (Tabel 8). Artinya, kemasan aluminium foil dan plastik mampu memberikan hasil $\mathrm{K}_{\mathrm{CT}}$ lebih baik dibanding kemasan kertas amplop. $\mathrm{K}_{\mathrm{CT}}$ benih secara umum meningkat di akhir periode simpan pada semua ruang simpan dan jenis kemasan dibandingkan $\mathrm{K}_{\mathrm{CT}}$ awal yaitu $7,60 \% \mathrm{KN} /$ etmal . Hal ini tidak sejalan dengan penelitian Waluyo et al. (2014) yang menunjukkan bahwa semakin lama benih bawang daun disimpan kecepatan berkecambah benihnya semakin menurun pada semua jenis kemasan dan ruang simpan. Hal ini menunjukkan vigor benih tetap dapat dipertahankan dengan baik selama 6 bulan penyimpanan.

Tabel 8. Kecepatan tumbuh benih (\%KN/etmal) benih kelor yang disimpan pada berbagai jenis kemasan dan ruang simpan selama 6 bulan

\begin{tabular}{llcccccc}
\hline \multirow{2}{*}{ Perlakuan } & \multicolumn{7}{c}{ Lama penyimpanan (BSS) } \\
\cline { 2 - 7 } & 1 & 2 & 3 & 4 & 5 & 6 \\
\hline 1 Jenis kemasan & 8,04 & 10,32 & 9,95 & $9,40^{\mathrm{a}}$ & $10,14^{\mathrm{b}}$ & 8,69 \\
& Plastik & 7,08 & 11,16 & 9,74 & $7,25^{\mathrm{b}}$ & $9,77^{\mathrm{b}}$ & 8,24 \\
& Kertas & 7,56 & 10,80 & 10,82 & $7,18^{\mathrm{b}}$ & $11,08^{\mathrm{a}}$ & 9,14 \\
& Aluminium foil & & & & & & \\
2 & Ruang simpan & 7,32 & 10,91 & 9,93 & 8,54 & 10,90 & 9,49 \\
& Suhu AC $\left(17-19^{0} \mathrm{C}\right)$ & 7,81 & 10,61 & 10,40 & 7,34 & 9,76 & 7,88 \\
\hline
\end{tabular}

Keterangan : angka yang diikuti huruf yang sama pada kolom yang sama menunjukkan tidak berbeda nyata dengan uji DMRT taraf $\alpha$ $=5 \%, \mathrm{BSS}=$ bulan setelah simpan

Interaksi perlakuan kemasan dan ruang simpan tidak berpengaruh nyata pada 6 BSS. Secara umum penyimpanan menggunakan plastik dan aluminium foil pada suhu AC maupun suhu kamar menunjukkan $\mathrm{K}_{\mathrm{CT}}$ lebih tinggi dibandingkan menggunakan kemasan kertas
(Gambar 3). Hal ini karena kemasan plastik dan aluminium foil terbuat dari bahan kedap udara dan uap air yang memiliki permeabilitas lebih kecil terhadap gas oksigen dibandingkan kemasan kertas, sehingga laju respirasi berjalan lebih lambat. 


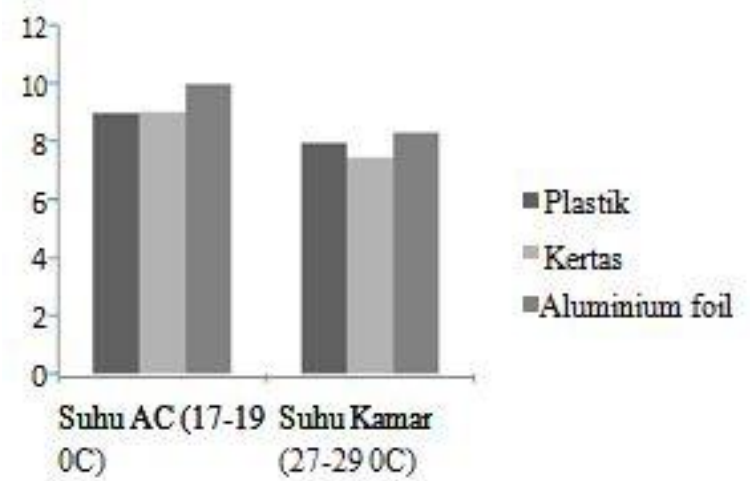

Gambar 3. Interaksi jenis kemasan dan suhu ruang simpan terhadap KCT benih pada 6 BSS

\section{KESIMPULAN}

First count dan final count untuk benih kelor jatuh pada hari ke-10 dan hari ke-15 setelah benih ditanam. Sayap pada benih kelor tidak menganggu perkecambahan benih. Tingkat kemasakan buah hijau kecoklatan maupun coklat tua sudah bisa dijadikan kriteria panen untuk benih kelor karena memiliki mutu fisiologis yang sama. Penyimpanan benih kelor dalam kemasan aluminium foil dan plastik pada suhu AC (17-19 $\left.{ }^{\circ} \mathrm{C}\right)$ dan suhu kamar $\left(27-29^{\circ} \mathrm{C}\right)$ memberikan hasil kadar air, viabilitas dan vigor lebih baik dibandingkan kemasan kertas. Penyimpanan benih selama 6 bulan dalam kemasan aluminium foil memberikan hasil rata-rata kadar air $(7,75 \%)$, viabilitas (PTM 86,22\%), dan vigor $\left(\mathrm{K}_{\mathrm{CT}} 9,58\right.$ $\% \mathrm{KN} /$ etmal) benih terbaik, sedangkan penyimpanan menggunakan plastik memberikan hasil rata-rata viabilitas (DB 82,11\%), dan vigor (IV 66,83\%) terbaik. Penyimpanan menggunakan suhu AC lebih baik dalam mempetahankan KA, viabilitas, dan vigor dibandingkan suhu kamar.

\section{DAFTAR PUSTAKA}

Desiawati, D. 2013. Tinjauan konservasi kelor (Moringa Oleifera Lam.) : studi kasus di desa Cikarawang Kecamatan Dramaga, Kabupaten Bogor [skripsi]. Institut Pertanian Bogor. Bogor.

Ilyas, S. 2012. Ilmu dan Teknologi Benih: Teori dan Hasil-hasil Penelitian. IPB Press, Bogor.

Indartono. 2011. Pengkajian suhu ruang penyimpanan dan teknik pengemasan terhadap kualitas benih kedelai. J. Gema Teknologi. 16(3):158-163.
Justice, O.L., L.N Bass. 2002. Prinsip dan praktek penyimpanan benih. In Roesli R. ( $E d s)$. Principle and Practices of Seed Storage. Jakarta (ID): Raja Grafindo Persada.

Kasolo, J.N., Bimenya, Ojok, Ochhieng, Okeng. 2010. Phytochemicals and uses of Moringa oleifera leaves in Ugandan rural communities. J. of Medicinal Plants Research. 4(9): 753-757.

Kompas. 2015. Kualitas terbaik di dunia, daun kelor asal timor diburu pembeli mancanegara. http://kompas.com [9 Januari 2016]

Kustiani, A. 2013. Pengembangan crackers sumber protein dan mineral dengan penambahan tepung daun kelor (Moringa oleifera L.) dan tepung badan - kepala ikan lele dumbo (Clarias gariepinus). Skripsi. Institut Pertanian Bogor. Bogor.

Kuswanto, H. 2003. Teknologi Pemrosesan, Pengolahan, dan Penyimpanan Benih. Yogyakarta(ID): Kanisius.

Mardiana, L. 2013. Daun Ajaib. Tumpas Penyakit Kanker, Diabetes, Ginjal, Hepatitis, Kolesterol, dan Jantung. Penebar swadaya, Jakarta.

Nazimah. 2010. Pengaruh kemasan dan periode simpan serta invigorasi terhadap viabilitas dan vigor benih purwoceng (Pimpinella pruatjan Molk.) [skripsi]. Institut Pertanian Bogor. bogor.

Radovich, T. 2009. Farm and forestry production and marketing profile for moringa (Moringa oleifera). [Internet] [diunduh 2016 Desember 26]. Tersedia pada http://agroforestry.net/scps 
Rahayu, E., E. Widajati. 2007. Pengaruh kemasan, kondisi ruang simpan dan periode simpan terhadap viabilitas benih caisin (Brassica chinensis L.). Bul.Agron. 35 (3):191-196.

Sadjad, S. 1993. Dari Benih Kepada Benih. Jakarta(ID): PT Gramedia Widiasarana Indonesia.

Sutopo, L. 2004. Teknologi Benih - edisi revisi. Jakarta(ID): Raja Grafindo Persada.

Waluyo, N., C. Azmi C., R. Kirana. 2014. Pengaruh jenis kemasan terhadap fisiologis benih bawang daun (Allium fistolosum) selama periode simpan. J. Agrin. 18 (2):148-157.

Widajati, E., E. Murniati, E.R. Palupi, T. Kartika, M.R. Suhartanto, A. Qodir. 2013. Dasar Ilmu dan Teknologi Benih IPB Press(ID): Bogor.

Winarno, H.H. 2014. Danrem : Spanyol dan Cina akan beli ribuan ton daun kelor NTT. [Internet] [diunduh 2016 Januari 18]. Tersedia pada http://m.merdeka.com 